\title{
REKONSTRUKSI HUKUM PERKAWINAN DIBAWAH TANGAN DALAM PERSPEKTIF FIQH BERDASARKAN NILAI KEMASLAHATAN
}

\author{
Munasir \\ Ketua YPAI Al-Karimah Demak \\ munasir00@
}

\begin{abstract}
Marriage is a physically and mentally bond between a man and a woman as husband and wife with the intention of forming a family or household happy and everlasting based on God. The dualism of the legal status of Islam in Indonesian society marriage is a problem that must be solved with emphasis on the value of the benefit. Methods used normative juridical method, this study sought to find out whether the law to be applied in order to solve a particular problem, in other words, normative juridical approach is the approach that examines the law as the norm. The results obtained are 1. that the marriage Construction under the hand according to Islamic jurisprudence Islamic marriage between husband and wife with Moslem or nonMoslem with a harmonious marriage include the willingness and consent qobul. Marriage is said to be valid if carried out in accordance with Islamic figh with the five pillars of marriage, namely a) Approval of the bride and groom, b) Mayor of marriage, c) Two witnesses, d) ljab qobul and d) Mahar. And reconstruction of marital law under the hand in the perspective of Islamic jurisprudence by requiring that the benefit of legal marriage should Replaces, ie the agreement of both bride and groom, guardian of marriage, two witnesses, the dowry, consent qobul and please register at KUA / civil records.
\end{abstract}

Keyword: Reconstruction Law, Marriage under the hand, the value of benefit

\begin{abstract}
Abstrak
Perkawinan adalah ikatan lahir batin antara seorang pria dan seorang wanita sebagai suami istri dengan tujuan membentuk keluarga atau rumah tangga yang bahagia dan kekal berdasarkan Ketuhanan Yang Maha Esa. Terjadinya dualisme status hukum perkawinan masyarakat Islam di Indonesia merupakan permasalahan yang harus diselesaikan dengan mengutamakan nilai kemaslahatan. Metode Penelitian yang dipakai menggunakan metode yuridis normatif, penelitian ini berusaha untuk menemukan apakah hukumnya yang sesuai untuk diterapkan guna menyelesaikan suatu masalah tertentu dengan kata lain, pendekatan yuridis normatif merupakan metode pendekatan yang mengkaji hukum sebagai norma. Hasil penelitian yang diperoleh yaitu 1.bahwa Konstruksi perkawinan dibawah tangan menurut figh islam perkawinan antara suami islam dengan istri beragama islam atau non muslim dengan rukun perkawinan meliputi kesediaan dan ijab qobul. Perkawinan dikatakan sah kalau dilaksanakan sesuai dengan fiqh islam dengan lima rukun pernikahan yaitu a) Persetujuan kedua mempelai, b) Wali nikah, c) Dua orang saksi, d) ljab qobul dan d) Mahar. Dan rekonstruksi hukum perkawinan dibawah tangan dalam perspektif figh islam berdasarkan kemaslahatan mensyaratkan bahwa hukum perkawinan harus diperbaruhi, yaitu kesepakatan kedua mempelai, wali nikah, dua orang saksi, mahar, ijab qobul dan di catatkan di KUA/Catatan sipil.
\end{abstract}

Kata Kunci: Rekonstruksi Hukum, Perkawinan bawah tangan, nilai kemaslahatan. 


\section{A. PENDAHULUAN}

Dalam kehidupan bermasyarakat dalam setiap bangsa, penilaian yang umum, bahwa orang yang berkeluarga atau pernah berkeluarga mempunyai kedudukan yang lebih dihargai dari mereka yang tidak kawin. Dalam Agama, perkawinan itu dianggap suatu lembaga yang suci. ${ }^{1}$

Perkawinan adalah ikatan lahir batin antara seorang pria dan seorang wanita sebagai suami istri dengan tujuan membentuk keluarga atau rumah tangga yang bahagia dan kekal berdasarkan Ketuhanan Yang Maha Esa. ${ }^{2}$

Proses pernikahan sebenarnya telah diakui, baik pihak hukum maupun agama, namun perkembangan zaman mengalami perubahan, maka timbul beberapa macam bentuk pernikahan, diantaranya adalah pernikahan resmi, pernikahan di bawah tangan dan pernikahan sirri. Ketiga istilah tersebut adalah istilah perkawinan di antara 2 manusia lain jenis, saling menyayangi, sepakat hidup bersama dan melaksanakan ijab qobul/sighat.

Zaman Nabi Muhammad pernikahan sah adalah pernikahan terdiri dari beberapa hal diantaranya: mempelai wanita, mempelai pria, mahar, wali, dan dua orang saksi, serta ijab qobul ${ }^{3}$. Kondisi itu sistem hukum belum tertata dan terbentuk seperti sekarang ini. Sebenarnya dalam nas tidak ada keterangan yang mewajibkan untuk mencatat perkawinan, namun ketika melihat ayat yang menerangkan ketika terjadi utang-piutang, maka diperintahkan agar mencatatnya, sebagaimana pada ayat 282 QS. Al-Baqarah:

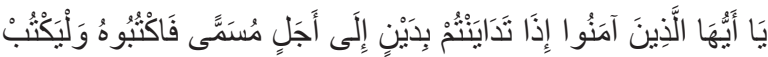

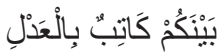

Artinya: "Hai orang-orang yang beriman, apabila kamu bermu'amalah tidak secara tunai untuk waktu yang ditentukan,

1 Mardani, 2001, Hukum Perkawinan Islam di Dunia Islam Modern, Graha Ilmu, Jakarta, hlm.5.

2 Lihat Pasal 1 Undang-Undang No. 1 Tahun 1974 tentang Perkawinan.

3 Lihat Pasal 14 Inpres Nomor 1 Tahun 1991 Tentang Kompilasi Hukum Islam Kompilasi Hukum Islam. hendaklah kamu menuliskannya. Hendaklah seorang penulis di antara kamu menuliskannya dengan benar......"

Ayat di atas dapat diambil makna: "jika tidak tercatat sama halnya dengan tidak ada akad. Undang-undang No. I Tahun $19 \vee$ \& Pasal $r$ menerangkan bahwa: ayat 1 "Perkawinan adalah sah, apabila dilakukan menurut hukum masing-masing agamanya dan kepercayaannya itu". Ayat $r$ "Tiap-tiap perkawinan dicatat menurut peraturan perundang-undangan yang berlaku"'.

Pasal 4 Inpres Nomor 1 Tahun 1991 Tentang Kompilasi Hukum Islam (KHI) menyebutkan perkawinan adalah sah, apabila dilakukan menurut hukum Islam sesuai dengan Pasal 2 ayat (1) Undang-undang Tentang Perkawinan disebutkan Perkawinan adalah sah jika dilakukan menurut hukum masingmasing agamanya dan kepercayaannya. ${ }^{5}$ Hal ini berarti bahwa Kompilasi Hukum Islam mengakomodasi Undang-undang Perkawinan Nomor 1 tahun 1974 tentang Perkawinan, walaupun Kompilasi Hukum Islam sudah menjadi kesepakatan tentang kekuatan mengikatnya.

Perkawinan ialah perjanjian penghalalan antara insan lain jenis dalam pergaulan yang membatasi hak dan kewajiban serta bertolong-menolong antara laki-laki dan perempuan yang bukan muhrim ${ }^{6}$ (wanita yang tidak ada jalinan darah). ${ }^{7}$

Sementara di masyarakat, banyak pelaksanaan perkawinan tanpa prosedur undang-undang disebut, perkawinan dibawah tangan. Perkawinan tersebut, merupakan

4 Lihat Undang-Undang Nomor 1 Tahun 1974 tentang Perkawinan pasal 2.

5 Lihat Pasal 2 ayat (1) Undang-Undang Nomor 1 Tahun 1974 Tentang Perkawinan.

6 Wanita mukhrim adalah wanita yang tidak boleh dinikahi sebagaiamana dalam Ayat Alqur'an ("diharamkan atas kamu (mengawini) ibu-ibumu; anak-anakmu yang perempuan; saudara-saudaramu yang perempuan, saudara-saudara bapakmu yang perempuan; saudarasaudara ibumu yang perempuan; anak-anak perempuan dari saudara-saudaramu yang laki-laki; anak-anak perempuan dari saudara-saudaramu yang perempuan," An Nisa, ayat 23.

7 Sudarsono, 1999, "Hukum Perkawinan Nasional", Penerbit, Rineka Cipta, Jakarta, hlm.2. 
pelaksanaan pernikahan sesuai dengan syarat rukun nikah dalam Islam atau sah menurut fiqh klasik, namun tidak dicatatkan di Kantor Urusan Agama (KUA) atau Petugas Pencatat Nikah (PPN). Dinamakan sirri karena dilangsungkan secara diam-diam, tertutup, rahasia atau sembunyi-sembunyi tanpa adanya publikasi pada masyarakat ${ }^{8}$.

Undang-undang perkawinan sebenarnya tidak mengenal perkawinan di bawah tangan atau nikah sirri, namun menurut MUI membagi tentang bentuk pernikahan yaitu perkawinan resmi, perkawinan di bawah tangan, dan perkawinan sirri. Disebutkan dalam fatwa MUI bahwa nikah di bawah tangan adalah pernikahan terpenuhi semua rukun dan syarat yang ditetapkan dalam fiqh klasik. Namun, pernikahan tersebut tanpa pencatatan resmi di instansi berwenang, sebagaimana diatur dalam perundangundangan. Konsep teoritis antara nikah sirri dan nikah di bawah tangan terdapat perbedaan, namun ranah realita masyarakat, di mata undang-undang tidak ada bedanya, keduanya marak terjadi dan memiliki faktorfaktor pemicu diantaranya faktor ekonomi, politis, tradisi dan faktor efisiensi ${ }^{9}$.

Negara Indonesia mengalamidualisme status hukum perkawinan masyarakat Islam, yaitu nikah yang sah menurut negara (tercatat) dan nikah sirri/nikah di bawah tangan (yang tidak tercatat). penelitian pada beberapa tempat di Indonesia, nikah sirri masih menduduki tempat yang cukup diminati oleh sebagian anggota masyarakat, terutama di daerah pedesaan, disamping nikah yang dilakukan secara tercatat. Keduanya merupakan nikah yang sah secara agama, karena memenuhi syarat dan rukun dalam hukum perkawinan Islam. Keduanya menjadi berbeda karena Undang-Undang Nomor 1 Tahun 1974 tentang Perkawinan pada Pasal 2 Ayat (2) menetapkan bahwa

8 Nurhaedi, 2003, Nikah di Bawah Tangan, Praktik Nikah Sirri Mahasiswa Jogja, Saujana, Yogyakarta, hlm.5.

9 Ensiklopedia masmuluk.Masmuluk.blogspot.com. http://gubukhukum.blogspotcom/2012/08/nikahdibawah-tangan.html. posting 30 agustus 2012 . di akses 19 September 2014. setiap perkawinan harus dicatat sesuai dengan peraturan perundang-undangan yang berlaku. Yang lebih memperihatinkan lagi adalah para oknum pejabat, Pengawai Negeri Sipil, bahkan para tokoh masyarakat, melaksanakan perkawinan dibawah tangan.

Pernikahan sah adalah menjalankan semua prosedur pernikahan dan tercatat di lembaga pemerintah yang menanganinya. Namun dilain pihak bahwa perkawinan bisa tercatat di lembaga pemerintah adalah bagi yang sudah cukup umur sebagaimana tercantum pada Undang-Undang Perkawinan No.1 tahun 1974 Pasal 6 dan 7, atau jika belum cukup umur harus mendapat ijin kedua orang tua. Di sisi lain permasalahan terjadi masyarakat bukan karena batasan umur, namun banyak alasan sebagai pemicu pelaksanaan perkawinan dibawah tangan diantaranya adalah: 1.Pernikahan di bawah umur, biasa disebut dengan pernikahan dini. Pernikahan tersebut biasanya terjadi karena pergaulan bebas dan terjadi kehamilan di luar nikah. 2.Pernikahan menurut agama sah, namun tidak dapat diijinkan oleh pemerintah, karena tidak dapat melengkapi persyaratan administrasi (istri kedua dan suami tidak mendapat ijin dari istri pertama) bahkan sengaja tidak akan dicatat di lembaga pemerintah dikarenakan banyak persyaratan tambahan dari pemerintah. 3.Khusus bagi pensiunan pegawai, dikarenakan istri syahnya sudah meninggal, dan hendak menikah lagi namun takut tunjangan hilang, maka yang bersangkutan memilih untuk menikah dibawah tangan ${ }^{10}$.

Terjadinya pernikahan dibawah tangan, dapat diidentifiksi beberapa hal diantaranya: 1.Ketidakpahaman masyarakat dengan perkembangan hukum di Indonesia. 2. Hanya menggunakan hukum fiqh saja, padahal lingkupnya terbatas pada pemeluk agama. 3 . Kurang kontrolnya orang tua terhadap putera puteri mereka, maka terjadi pergaulan bebas para remaja, akhirnya menimbulkan hamil di luar nikah. 4.Tidak adanya sanksi kongkrit

10 Abdurahman, 1986, Himpunan Peraturan Perundang-undangan tentang Perkawinan, Akademika, Jakarta, 1986, hlm.57. 
pada kegiatan perkawinan di bawah tangan. 5.Ketidak pahaman bahwa perkawinan dibawah tangan merupakan tindakan melawan hukum. 6. dan faktor-faktor lain diantaranya adalah faktor politik, ekonomi serta faktor efisiensi. Perkawinan dibawah tangan mempunyai banyak faktor pemicu sebagaimana terulas pada paragraf di atas, namun dampak dari perkawinan di bawah tangan, bukan hanya sekedar menimpa kedua pasangan, namun menimpa pada keturunan mereka, diantaranya pada akta kelahiran, standar akta kelahiran adalah bernasab bapak dan ibu, namun anak yang dilahirkan dari hasil perkawinan di bawah tangan, tidak dapat mempunyai nasab ayah, dikarenakan pernikahan di bawah tangan tidak diakui oleh hukum positif yaitu sebagaimana di atur pada Undang-undang No.1 tahun 1974.

Melihat kejadian perkawinan di bawah tangan, yang dilakukan oleh kalangan muslim pengikut fiqh klasik, serta yang dilakukan oleh para oknum pejabat, PNS, dan tokoh masyarakat, maka dapat dilihat bahwa dampaknya: tidak ada maslakhat, tidak adanya keadilan hukum, tidak adanya kemanfaatan hukum, dan tidak ada kepastian hukum.

Berdasarkan latar belakang untuk penelitian di atas, maka penulis dapat merumuskan beberapa permasalahan sebagai berikut:

1. Bagaimana kontruksi perkawinan dibawah tangan dalam perspektif figh Islam?

2. Bagaimana rekonstruksi hukum perkawinan dibawah tangan dalam perspektif fiqh Islam berdasarkan nilai kemaslahatan?

\section{B. METODE PENELITIAN}

Metode Penelitian yang dipakai menggunakan metode yuridis normatif, penelitian ini berusaha untuk menemukan apakah hukumnya yang sesuai untuk diterapkan guna menyelesaikan suatu masalah tertentu dengan kata lain, pendekatan yuridis normatif merupakan metode pendekatan yang mengkaji hukum sebagai norma. ${ }^{11}$

11 Ronny Hanitijo Soemitro, 1994, Metodologi Penelitian Hukum dan Jurimetri, Ghalia Indonesia, Jakarta, hlm.22.
Spesifikasi penelitian yang digunakan adalah spesifikasi deskriptif analitis, karena penelitian yang dimaksud, menggambarkan tentang manusia, keadaan dan gejala-gejala lainnya. ${ }^{12}$ Penelitian deskriptif analitis juga berusaha menggambarkan masalah hukum, sistem hukum dan mengkajinya atau menganalisisnya sesuai dengan kebutuhan dari penelitian bersangkutan.

Penulis akan mendeskripsikan jawaban ketiga permasalahan disertasi secara apa adanya dan kemudian akan menganalisis ketiga permasalahan disertasi dengan menggunakan teori kemaslahatan. Dengan demikian akan diperoleh gambaran secara rinci tentang berbagai hal yang terkait dengan perkawinan di bawah tangan dan diselesaikan atau direkontruksi berdasarkan teori kemaslahatan.

\section{HASIL DAN PEMBAHASAN}

1. Kontruksi Perkawinan Dibawah Tangan Dalam Perspektif Fiqh Islam.

Konstruksi perkawinan dibawah tangan menurut fiqh islam adalah perkawinan antara suami islam dengan istri beragama islam atau non muslim dengan rukun perkawinan meliputi kesediaan dan ijab qobul. Perkawinan dikatakan sah kalau dilaksanakan sesuai dengan fiqh islam dengan lima rukun sebagai pembahasan Rukun Pernikahan Dibawah Tangan dalam Perspektif Fiqh Islam:

1. Persetujuan kedua mempelai Persetujuan dari kedua belah pihak merupakan rukun yang sebenarnya bagi akad nikah. Sedangkan ljab dan Qabul hanya merupakan manifestasi dari persetujuan tersebut. Dengan kata lain kedua belah pihak harus memperlihatkan secara jelas adanya persetujuan dan kesepakatan tersebut pada waktu akad nikah berlangsung. Adapun bentuk kalimat yang dipakai

12 Bambang Sunggono, 1997 Metodologi Penelitian Hukum, Rajawali Press, Jakarta, hlm.36. 
menurut syari'at bagi sebuah akad nikah adalah bentuk madhi. Yang demikian itu, juga karena adanya persetujuan dari kedua belah pihak yang bersifat pasti dan tidak mengandung persetujuan lain.

2. Wali nikah

Yang dikatakan wali adalah orang yang paling dekat dengan mempelai wanita. Dan orang paling berhak menikahkan seorang wanita merdeka adalah ayahnya, lalu kakeknya, dan seterusnya berdasarkan garis keturunan keatas. Selain itu boleh juga anaknya dan cucunya, kemudian saudara seayah seibu, kemudian saudara seayah, kemudian paman.

Disyaratkan adanya wali bagi wanita. Islam mensyaratkan adanya wali bagi wanita sebagai penghormatan bagi wanita, memuliakan dan menjaga masa depan mereka. Walinya lebih mengetahui daripada wanita tersebut. Jadi bagi wanita, wajib ada wali yang membimbing urusannya, mengurus aqad nikahnya. Tidak boleh bagi seorang wanita menikah tanpa wali, dan apabila ini terjadi maka tidak sah pernikahannya.

Wali nikah dibagi menjadi 2 macam yaitu wali nasab dan wali hakim:

1. Wali nasab yaitu wali yang mempunyai pertalian darah dengan mempelai wanita yang akan dinikahkan.

Adapun Susunan urutan wali nasab adalah sebagai berikut :

a. Ayah kandung, ayah tiri tidak syah jadi wali.

b. Kakek (ayah dari ayah mempelai perempuan) dan seterusnya ke atas. c. Saudara laki-laki sekandung.

d. Saudara laki-laki seayah.

e. Anak laki-laki dari saudara laki-laki sekandung.

f. Anak laki-laki dari saudara laki-laki seayah

g. Saudara laki-laki ayah yang seayah dengan ayah.

h. Anak laki-laki dari sdr laki-laki ayah yang sekandung dengan ayah.

i. Anak laki-laki dari saudara laki-laki ayah yang seayah dengan ayah

2. Wali hakim, yaitu seorang kepala Negara yang beragama Islam.

Di Indonesia, wewenang presiden sebagai wali hakim dilimpahkan kepada pembantunya yaitu Menteri Agama. Kemudian menteri agama mengangkat pembantunya untuk bertindak sebagai wali hakim, yaitu Kepala Kantor Urusan Agama Islam yang berada di setiap kecamatan. Wali hakim akan bertindak sebagai wali nikah apabila memenuhi kondisi sebagai berikut :

a. Wali nasab benar-benar tidak ada.

b. Wali yang lebih dekat (aqrob) tidak memenuhi syarat dan wali yang lebih jauh ( $a b^{\prime}$ 'ad) tidak ada.

c. Wali aqrob bepergian jauh dan tidak memberi kuasa kepada wali 
nasab urutan berikutnya untuk berindak sebagai wali nikah.

d. Wali nasab sedang berikhram haji atau umroh

e. Wali yang lebih dekat masuk penjara sehingga tidak dapat bertindak sebagai wali nikah

f. Wali yang lebih dekat hilang sehingga tidak diketahui tempat tinggalnya.

3. Dua orang saksi

Adapun syarat saksi yang menghadiri akad nikah haruslah dua orang laki-laki, muslim, baligh, berakal, melihat dan mendengar serta mengerti (paham) akan maksud akad nikah. Adapun kewajiban adanya saksi tidak lain, hanyalah untuk kemaslahatan kedua belah pihak dan masyarakat. Misalnya, salah seorang mengingkari, hal itu dapat dielakkan oleh adanya dua orang saksi. Juga misalnya apabila terjadi kecurigaan masyarakat, maka dua orang saksi dapatlah menjadi pembela terhadap adanya akad perkawinan dari sepasang suami istri. Disamping itu, menyangkut pula keturunan apakah benar yang lahir adalah dari perkawinan suami istri tersebut. Dan disinilah saksi itu dapatmemberikankesaksiannya. ${ }^{13}$

4. ljab qobul

Akad nikah merupakan perjanjian yang dilakukan antara dua pihak yang akan melaksanakan perkawinan yang diwujudkan dalam bentuk ijab dan qabul. ljab yaitu pernyataan dari pihak perempuan yang diwakili oleh wali,

13 Aunullah Indi, 2008, Ensiklopedi Fiqh, pustaka insani madani Yogyakarta, hlm.4. sedangkan qabul yaitu pernyataan menerima keinginan dari pihak pertama untuk menerima maksud tersebut.

Mengenai akad nikah yang berupa ijab dan qabul antara lelaki yang melamar dan wanita yang dilamar para ulama sepakat bahwa hal tersebut (ijab dan qabul) merupakan salah satu rukun dari pernikahan. Oleh karena itu sudah menjadi kewajiban bagi seseorang yang akan menikah untuk mengucapkan akad nikah yang berupa ijab yang dilakukan oleh wali dari pihak perempuan dan qabul yang diucapkan oleh mempelai pria atau wakilnya dengan ketentuan mempelai pria harus memberikan kuasa yang tegas dan secara tertulis bahwa ia (calon mempelai pria) mewakilkan akad pernikahannya pada wakilnya. Makna ijab dan qabul dalam sebuah perkawinan bukan hanya sekedar perjanjian yang bersifat keperdataan, akan tetapi lebih dari itu, yaitu suatu perjanjian yang kuat yang bukan hanya disaksikan oleh orang yang menghadirinya akan tetapi disaksikan oleh Allah.

5. Mahar

Mahar adalah sesuatu yang diberikan kepada isteri berupa harta atau selainnya dengan sebab pernikahan. Mahar (atau diistilahkan dengan mas kawin) adalah hak seorang wanita yang harus dibayar oleh lakilaki yang akan menikahinya. Mahar merupakan milik seorang isteri dan tidak boleh seorang pun mengambilnya, baik ayah maupun yang lainnya, kecuali dengan keridhaannya.

Pencatatan pernikahan menjadi syarat sah pernikahan sebagaimana Undang-Undang Nomor 1 Tahun 1974 
tentang perkawinan, bahwa pernikahan dapat dilaksanakan sesuai agama dan adat masing-masing kemudian pernikahan yang sah adalah pernikahan yang dicatat oleh pegawai pencatat nikah, adapun hasil pembahasan pernikahan berdasarkan fiqh dapat di baca pada tabel berikut:

Rukun Pernikahan Menurut 4 Madzhab

\begin{tabular}{|l|c|c|c|c|c|c|}
\hline Madzhab & \multicolumn{7}{|c|}{ Rukun } \\
\hline & \multicolumn{2}{|l|}{ Mempelai } & Mahar & $\begin{array}{c}\text { Wali } \\
\text { Nikah }\end{array}$ & $\begin{array}{c}\text { Dua Orang } \\
\text { Saksi }\end{array}$ & $\begin{array}{c}\text { ljab } \\
\text { Qobul }\end{array}$ \\
\hline & Putra & Putri & & & & \\
\hline Khanafi & - & - & - & - & - & $\sqrt{ }$ \\
\hline Maliki & $\sqrt{ }$ & $\sqrt{ }$ & $\sqrt{ }$ & $\sqrt{ }$ & - & $\sqrt{ }$ \\
\hline Syafi'i & $\sqrt{ }$ & $\sqrt{ }$ & - & $\sqrt{ }$ & $\sqrt{ }$ & $\sqrt{ }$ \\
\hline Hanbali & $\sqrt{ }$ & $\sqrt{ }$ & $\sqrt{ }$ & $\sqrt{ }$ & $\sqrt{ }$ & $\sqrt{ }$ \\
\hline
\end{tabular}

Berdasarkan pendapat empat madzhab tersebut, disimpulkan pada table,

maka dapat dilihat perbedaan pendapat para mazhab, disitu Nampak jelas bahwa fiqh merupakan hasil karya manusia, dan terdapat perbedaan sesuai kondisi masyarakat yang berlaku. Maka hal ini sesuai dengan pendapat Khisni pada buku Hukum Islam bahwa figh merupakan hasil karya manusia bisa berubah disesuaikan dengan zamannya ${ }^{14}$.

Penulis mengambil kesimpulan bahwa rukun perkawinan sebenarnya untuk mencari kemaslahatan, agar tidak terjadi permasalahan eksternal setelah pernikahan, bearti dengan ini bahwa penambahan pencatatan perkawinan adalah suatu kemaslahatan, bahkan jika merujuk pada penegakkan hukum menjadi wajib adanya pencatatan perkawinan.

Berdasarkan teori kemaslahatan (maslahah mursalah ${ }^{15}$ ) dari imam sayatibi berdasarkan lima hal yang harus di jaga yaitu: menjaga keturunan, harta, nyawa, agama, dan menjaga akal. Hal itu menjadi teori rekontruksi pencatatan perkawinan, terutama pada menjaga keturunan agar tetap terjaga nasab dan mendapatkan akta kelahiran bernasabkan ayah ibu, selain itu juga untuk mengantisipasi permasalahan setelah terjadi pernikahan, sebagaimana pemabahasan sebelumnya, termasuk dampak perkawinan di bawah tangan, pembagian waris dan hak hak setelah perkawinan agar terpenuhi berdasarkan kemaslahatan.

Maka rukun perkawinan menjadi tambah secara administrasi, yaitu pencatatan perkawinan menjadi rukun dan syarat nomor 6 , sebagai mana tabel fiqh pernikahan kontemporer:

\begin{tabular}{|l|c|c|c|c|c|c|c|}
\hline \multicolumn{1}{|c|}{ Madzhab } & \multicolumn{9}{|c|}{ Rukun } \\
\hline & \multicolumn{2}{|c|}{ Mempelai } & Mahar & $\begin{array}{c}\text { Wali } \\
\text { Nikah }\end{array}$ & $\begin{array}{c}\text { Dua } \\
\text { Orang } \\
\text { Saksi }\end{array}$ & $\begin{array}{c}\text { ljab } \\
\text { Qobul }\end{array}$ & $\begin{array}{c}\text { Pencatatan } \\
\text { di KUA }\end{array}$ \\
\hline & Putra & Putri & & & & & \\
\hline Khanafi & - & - & - & - & - & $\sqrt{ }$ & \\
\hline Maliki & $\sqrt{ }$ & $\sqrt{ }$ & $\sqrt{ }$ & $\sqrt{ }$ & - & $\sqrt{ }$ & \\
\hline Syafi'i & $\sqrt{ }$ & $\sqrt{ }$ & - & $\sqrt{ }$ & $\sqrt{ }$ & $\sqrt{ }$ & \\
\hline Hambali & $\sqrt{ }$ & $\sqrt{ }$ & $\sqrt{ }$ & $\sqrt{ }$ & $\sqrt{ }$ & $\sqrt{ }$ & \\
\hline Kontemporer & $\sqrt{ }$ & $\sqrt{ }$ & $\sqrt{ }$ & $\sqrt{ }$ & $\sqrt{ }$ & $\sqrt{ }$ & $\sqrt{ }$ \\
\hline
\end{tabular}

Nilai kemaslahatan adalah menjaga keturunan, agar mendapat haknya, dan

14 Akhmat Khisni, 2014, Hukum Islam, UNISSULA Press Cet.3, Semarang, hlm.16-17.

15 Hifdun nafs, khifdzu aqli, khifdul mal, dan khifdunasl.khifz addin baca Asy-Syatiby, Tanpa tahun, Al-Muwafaqat, fi Ushulisy Syari'ah, Juz II, Darul Kutub Al-IImiyyah, Beirut, hlm.7. 
tidak ada diskriminasi dengan anak-anak lainnya dalam arti, sama haknya.

Hal inisecepatnya di sosialisasikan kepada semua tokoh dan masyarakat, jika pencatatan tidak dilakukan maka seyogyanya di amankan dan dilaporkan kepada yang berwajib.

2. Rekonstruksi Hukum Perkawinan Dibawah Tangan Dalam Perspektif Fiqh Islam Berdasarkan Nilai Kemaslahatan

Pencatatan pernikahan merupakan produk ijtihad yang dilakukan oleh pemerintah dan tentunya bersifat mengikat dan memaksa, namun pemahaman masyarakat yang masih condong semata-mata hanya fiqh klasik yang digunakan oleh kaum Muslim.

Sebagaimana pembahasan bahwa penggalian Hukum Islam disebut ijtihad. ljtihad pada fiqih mempunyai dua pengertian, yaitu:

1. ljtihad sesungguhnya penalaran guna menentukan suatu pilihan saat seseorang tidak mempunyai suatu pegangan yang pasti dalam hukum sebelumnya, hal ini harus memilih dan menentukan hukum dengan pemahamana dan sangkaan akhirnya dijadikan pegangan guna menentukan atau melakukan sesuatu.

2. ljtihad mengacu kepada penalaran ilmiah. ljtihad jika terdapat di lingkup peradilan dan kekuasan kehakiman hukumnya fardhu kifayah. ${ }^{16}$

IImu figh merupakan produk ijtihad perorangan, maka jika dialihkan menjadi putusan hakim atau pemerintah akan mempunyai kekuatan yang mengikat. Dikarenakan jika bersifat bimbingan, anjuran atau nasihat atau menyangkut apa saja yang tidak terikat dengan putusan hakim atau keputusan pemerintah, maka bersetatus sebagai fatwa dengan kata lain adalah nasihat saja yang tidak mengikat, tetapi ia mengikat secara moral dan keimanan bagi seseorang,

16 Ali Yafi, 1994, Menggagas Fikih Sosial, Cetakan I, Mizan, Bandung, hlm.114-117. namun secara kenegaraan tidak bisa menjadi peraturan yang kuat.

Adapun hukum yang bersumber dari Allah S.W.T. untuk selanjutnya lebih dikonkretkan dan diselaraskan dengan kebutuhan zamannya melalui ijtihad atau penemuan hukum oleh para mujtahid dan para pakar dibidangnya masing-masing, baik secara perorangan, kolektif maupun oleh para hakim Pengadilan Agama dalam penangan suatu kasus. Namun lebih baiknya diputuskan melewati rapat besar Dewan Perwakilan Rakyat (DPR) dan terbentuk menjadi undang-undang, akhirnya pada pencatatan penikahan merupakan syarat sahnya pernikahan yang terdapat pada Undang-Undang Nomor 1 Tahun 1974.

Sebagaimana menurut Hafiz bahwa Kata hukum yang dikenal dalam bahasa Indonesia berasal dari bahasa Arab yang berarti putusan (judgement) atau ketetapan (provision). Dalam buku Ensiklopedia Hukum Islam, bahwa hukum berarti menetapkan sesuatu atas sesuatu atau meniadakannya. ${ }^{17} \mathrm{Hal}$ ini senada dengan penjelasan yang terdapat pada A Dictionary of Law yaitu, bahwa "Law is the enfoceable body of rules that govern any society or one of the rules making up the body of law, such as Act of Parliament." ${ }^{18}$ (Hukum adalah suatu kumpulan aturan yang dapat dilaksanakan untuk mengatur/memerintah masyarakat atau aturan apa pun yang dibuat sebagai suatu aturan hukum seperti tindakan dari parlemen).

Putusan hakim Peradilan Agama, baik yang merupakan putusan hakim Pengadilan Agama, putusan hakim Pengadilan Tinggi Agama maupun putusan hakim Mahkamah Agung RI adalah putusan yang berdasarkan Hukum Islam. Maka sudah barang tentu

17 H. A. Hafizh Dasuki, 1997, Ensiklopedia Hukum Islam, PT Ichtiar Baru van Hoeve, Jakarta, hlm.571.

18 Elizabeth A. Martin (editor), 1997, A Dictionary of Law, Oxford University Press, Fourth Edition, New York, hlm.259. 
termasuk adanya pencatatan pernikahan merupakan hal yang harus dilakukan dan bentuknya jelas mengikat bahwa pernikahan tersebut kedua belah pihak memberikan hak dan kwajiban masingmasing, dan kejelasan status keluarga tersebut.

Adapun dari segi kemaslahatan bahwa pernikahan yang dicatat akan membawa banyak kemaslahatan dibanding tidak diacatatkan, karena itu sudah bukan hanya sekedar sangkaan, namun sudah terdapat kasus-kasus sebagaimana dibahas di bab sebelumnya. Kemaslahatan dapat di runut dari pendapatnya imam Satibi, yaitu salah satu dari lima pilar maqosidu assar'i pada bidang hifdhu annasl (menjaga, melindungi keturunan), perlindungan tersebut terwujud dalam bentuk mengikat seorang suami menafkahi istri, merawat melindungi anak secara moral dan materiil serta formal.

Rekonstruksi nilai dari perkawinan di bawah tangan berdasarkan figh islam wajib dicatatkan di KUA bagi yang beragama islam dan memberikan sanksi pidana bagi mereka yang melaksanakan perkawinan di bawah tangan.

Adapun rekontstruksi hukum perkawinan di bawah tangan dalam perspektif fiqh islam berdasarkan nilai kemaslahatan di sebut teori hukum maslahat sebagai berikut:

Tabel Kesimpulan Rokenstruksi

\section{Perkawinan}

\begin{tabular}{|c|c|}
\hline $\begin{array}{ll} & \text { Rukun Pernikahan } \\
\text { Sebelum Di Rekonstruksi } \\
\text { 1. } & \text { Persetujuan kedua } \\
& \text { mempelai } \\
\text { 2. } & \text { Wali nikah } \\
\text { 3. Dua orang saksi } \\
\text { 4. ljab qobul } \\
\text { 5. }\end{array}$ & $\begin{array}{ll} & \text { Rukun Pernikahan } \\
\text { Sesudah Di Rekonstruksi } \\
\text { 1. } & \text { Persetujuan kedua } \\
& \text { mempelai } \\
\text { 2. } & \text { Wali nikah } \\
\text { 3. } & \text { Dua orang saksi } \\
\text { 4. } & \text { ljab qobul } \\
\text { 5. } & \text { Mahar } \\
\text { 6. } & \text { Dicatatkan dalam KUA/ } \\
& \text { Catatan Sipil } \\
\end{array}$ \\
\hline
\end{tabular}

Rekonstruksi tersebut berawal

5 rukun kemudian menjadi enam rukun yaitu ada penambahan pada nomor enam tentang pencatatan perkawinan di KUA bagi yang beragama muslim, atau di catatan sipil bagi yang berminat dicatatakan pada catatan sipil. Dengan bergitu perjanjian semakin kuat dan bagi yang tidak menjalankan sesuai rekonstruksi tersebut akan mendapat sanksi.

\section{PENUTUP}

\section{KESIMPULAN}

1. Konstsruksi perkawinan dibawah tangan dalam perspektif figh Islam. Konstruksi perkawinan dibawah tangan menurut fiqh islam adalah perkawinan antara suami islam dengan istri beragama islam atau non muslim dengan rukun perkawinan meliputi kesediaan dan ijab qobul. Perkawinan dikatakan sah kalau dilaksanakan sesuai dengan fiqh islam dengan lima rukun pernikahan. Sebagaimana tabel di bawah ini:

\begin{tabular}{|ll|}
\hline & $\begin{array}{l}\text { Rukun Pernikahan Di Bawah Tangan dalam } \\
\text { Perspektif Fiqh Islam }\end{array}$ \\
\hline 1. & Persetujuan kedua mempelai \\
2. & Wali nikah \\
3. & Dua orang saksi \\
4. & ljab qobul \\
5. & Mahar \\
\hline
\end{tabular}

2. Rekonstruksi hukum perkawinan dibawah tangan dalam perspektif fiqh islam berdasarkan kemaslahatan mensyaratkan bahwa hukum perkawinan harus diperbaruhi, yaitu kesepakatan kedua mempelai, wali nikah, dua orang saksi, mahar, ijab qobul dan di catatkan di KUA/Catatan sipil. Sebagaimana tabel berikut:

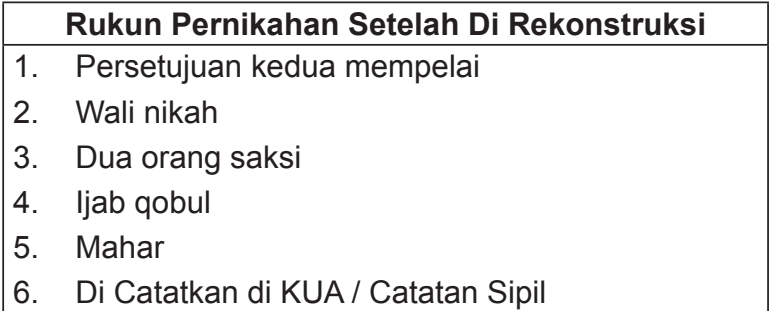

\section{SARAN}

1. Harus ada semacam pengawas yang mengawasi perkawinan di Indonesia 
apakah telah dicatatkan di KUA atau belum di catatkan di KUA.

2. Pembentukan komisi yang khusus menangani perkawinan di bawah tangan dan memberikan sanksi bagi perkawinan yang tidak dicatatkan di KUA.

\section{DAFTAR PUSTAKA}

\section{- Buku-Buku :}

Abdurahman, 1986, Himpunan Peraturan Perundang-undangan tentang Perkawinan, Akademika, Jakarta.

Akhmat Khisni, 2014, Hukum Islam, UNISSULA Press Cet.3, Semarang.

Ali Yafi, 1994, Menggagas Fikih Sosial, Cetakan I, Mizan, Bandung

Aunullah Indi, 2008, Ensiklopedi Fiqh, Pustaka Insan-Madani Yogyakarta.

Asy-Syatiby, Tanpa tahun, Al-Muwafaqat, fi Ushulisy Syari'ah, Juz II, Darul Kutub AI-IImiyyah, Beirut,

Bambang Sunggono, 1997 Metodologi Penelitian Hukum, Rajawali Press, Jakarta,

Cipta Nurhaedi, 2003, Nikah di Bawah Tangan, Praktik Nikah Sirri Mahasiswa Jogja, Saujana, Yogyakarta.

Elizabeth A. Martin (editor), 1997, A Dictionary of Law, Oxford University Press, Fourth Edition, New York.

H.A.Hafizh Dasuki, 1997, Ensiklopedia Hukum Islam, PT Ichtiar Baru van Hoeve, Jakarta. Mardani, 2001, Hukum Perkawinan Islam di Dunia Islam Modern, Graha Ilmu, Jakarta.

Ronny Hanitijo Soemitro, 1994, Metodologi Penelitian Hukum dan Jurimetri, Ghalia Indonesia, Jakarta.

- Peraturan Perundang-Undangan:

Undang-Undang Nomor 1 Tahun 1974

$\mathrm{KHI}$

\section{- Website}

Ensiklopedia masmuluk.Masmuluk.blogspot.com.http://gubukhukum.blogspotcom/2012/08/ nikah-dibawah-tangan.html. posting 30 agustus 2012 